\title{
Evaluation of Serum Adenosine Deaminase in Cystic Fibrosis Patients in an Iranian Referral Hospital
}

\author{
Fatemeh Farahmand, ${ }^{1,2}$ Parisa Tajdini, ${ }^{3,{ }^{*}}$ Gholamhossein Falahi, ${ }^{1,2}$ Sedigheh Shams, ${ }^{2,3}$ and Shima \\ Mahmoudi $^{4}$ \\ ${ }^{1}$ Department of Pediatrics, Tehran University of Medical Sciences, Tehran, IR Iran \\ ${ }^{2}$ Children's Medical Center, Pediatrics Center of Excellence, Tehran, IR Iran \\ ${ }^{3}$ Growth and Development Research Center, Tehran University of Medical Sciences, Tehran, IR Iran \\ ${ }^{4}$ Pediatric Infectious Disease Research Center, Tehran University of Medical Sciences, Tehran, IR Iran \\ "Corresponding author: Parisa Tajdini, Growth and Development Research Center, Tehran University of Medical Sciences, Tehran, IR Iran. E-mail: ptajdini@irimc.org
}

Received 2015 February 20; Revised 2015 April 22; Accepted 2015 May 05.

\begin{abstract}
Background: Adenosine, a signaling nucleoside, is controlled in part by the enzyme adenosine deaminase (ADA). There are rare reports on the role of adenosine levels and $\mathrm{ADA}$ in cystic fibrosis $(\mathrm{CF})$ patients.

Objectives: The aim of this study was to assess serum ADA in CF patients in order to find whether the severity of lung disease in CF is related to significant changes of ADA or not.

Patients and Methods: Venous blood serum ADA was measured in CF patients (3-15 years) and 49 healthy children (3-15 years) referred to Children's Medical Center. Classification of respiratory and gastrointestinal disease severity in CF patients as well as Body Mass Index (BMI) was performed. The results were compared with values obtained from healthy children matched for age and gender.

Results: This study included 49 children of both genders (20 females and 29 males) with CF (mean age: $6.36 \pm 2.22$ years). Mean serum ADA in CF patients group and control group was $9.38 \pm 2.72$ and $16.04 \pm 1.27$, respectively (P value $=0.001$ ). Mean serum ADA in CF patients with normal BMI was higher than in patients with low BMI (P value $=0.002$ ).

Conclusions: In this study the lower serum level of ADA was seen in CF patients compared to control group. The clinical symptoms, especially respiratory symptoms, in CF patients might be associated with reduction of serum ADA and rising serum adenosine; therefore, further studies on the use of ADA enzyme therapy in CF patients are highly recommended.
\end{abstract}

Keywords: Adenosine Deaminase, Cystic Fibrosis, Children

\section{Background}

Cystic Fibrosis (CF) is an autosomal recessive genetic disorder caused by mutations in the cystic fibrosis transmembrane conductance regulator (CFTR) gene. Adenosine, a signaling nucleoside, has both tissue-protective and tissue-destructive effects and its level in tissues is controlled in part by the enzyme adenosine deaminase (ADA) (1).

ADA is an enzyme of the purine metabolism. There are two isoenzymes of ADA in humans mainly in two forms of adenosine deaminase $1\left(\mathrm{ADA}_{1}\right)$ and adenosine deaminase 2 $\left(\mathrm{ADA}_{2}\right)(2)$. Adenosine has 3 receptors including $\mathrm{A} 1, \mathrm{~A} 2 \mathrm{~B}$, and A3. Adenosine produces cytokine through $\mathrm{A} 2 \mathrm{~B}$ receptor and increases production of mucus and eosinophill cells in respiratory system through $\mathrm{A} 3$ receptor $(3,4)$. Adenosine level rises in cellular damage, cellular stress, hypoxia and reduced ADA (5). Deficiency of ADA conduces to pulmonary inflammation in $\operatorname{SCID}(6,7)$. In addition, the elevated level of ADA was demonstrated in several infections such as tuberculosis $(8,9)$ and upper respiratory tract infection (10), while in chronic obstructive pulmonary disease (COPD) and asthma its level was decreased (11, 12). It has been suggested that adenosine signaling might play a role in the pathogenesis of fibrosis in many disorders such as hepatic fibrosis, cirrhosis and chronic renal scarring in patients with glomerulonephritis (1). Tissue damage is observed in CF caused by activation of macrophages and Tlymphocytes that release myeloperoxidase (MPO) and ADA (13).

According to a previous experimental study, adenosine was accumulated in multiple tissues including the lung of ADA-deficient mice which was supposed to contribute to the development of pulmonary inflammation (1).

\section{Objectives}

There are rare reports on the role of adenosine level and ADA in CF patients. The aim of this study was to assess serum ADA in CF patients in order to find whether 
the severity of lung disease in CF is related to significant changes of ADA or not.

\section{Patients and Methods}

Between October 2013 and February 2014, 49 patients with CF and 49 healthy controls were recruited at gastroenterology clinic of Children's Medical Center in Tehran, Iran. Case and Control individuals were 3 to 15 years old. The Control group had no previous history of functional abdominal pain and had no symptoms during the study. Written informed consent was obtained from participant's parents or legal guardian. Requirements for a CF diagnosis included either positive genetic testing or positive sweat chloride test findings and at least one clinical manifestation including typical chronic obstructive pulmonary disease (COPD), documented exocrine pancreatic insufficiency, and positive family history (usually an affected sibling) (14).

The sweat test was performed according to Clinical and Laboratory Standards Institute guidelines. A sweat chloride level $\geq 60 \mathrm{mmol} / \mathrm{L}$ was interpreted as within the $\mathrm{CF}$ range, $30-60 \mathrm{mmol} / \mathrm{L}$ as equivocal, and $\leq 29 \mathrm{mmol}$ as normal (15). Classification of respiratory disease severity was based on the number of hospital admissions during the year, radiographic findings and the presence of exertional dyspnea. Classification of gastrointestinal disease severity was based on the sufficiency/insufficiency of pancreas. BMI was obtained according to children's sex and age.

$1 \mathrm{cc}$ venous blood sample was taken and serum ADA measured using ADA kit (Diazyme Laboratories Company, California, USA). The results were expressed in unit per liter $(\mathrm{U} / \mathrm{L})$.

Data are presented as the mean \pm standard deviation (SD) (normally distributed variables), Group comparisons were performed using the Student's t test or ANOVA test. Statistical significance was defined as $\mathrm{P}<0.05$. All analyses were performed with IBM SPSS Statistics.

\section{Results}

The study included 49 children (mean age: $6.36 \pm 2.22$ years) of both genders (20 females and 29 males) with CF. The characteristics of CF patients are shown in Table 1. Among control individuals (mean age $6.14 \pm 2.26 .24$ years) 24 were females and 25 males.

Mean serum ADA in CF patients group and control group was $9.38 \pm 2.72$ and $16.04 \pm 1.27$, respectively (P value $=0.001$ ). Mean serum ADA in CF patients with mild respiratory involvement was $10.8 \pm 2.45$, whereas it was with 7.14 \pm 1.19 higher than in CF patients with severe respiratory ( $\mathrm{P}$
Table 1. CF Patients' Characteristics ${ }^{\text {a }}$

\begin{tabular}{|c|c|}
\hline Variables & Values \\
\hline \multicolumn{2}{|l|}{ Gender } \\
\hline Male & $20(41)$ \\
\hline Female & $29(59)$ \\
\hline \multicolumn{2}{|l|}{ Consanguinity of parents } \\
\hline Near consanguinity & $18(38)$ \\
\hline $\mathrm{h}$ distant consanguinity & $5(10)$ \\
\hline No consanguinity & $6(12)$ \\
\hline \multicolumn{2}{|l|}{ Body Mass Index (BMI) } \\
\hline Normal & $29(59)$ \\
\hline Abnormal & $20(41)$ \\
\hline \multicolumn{2}{|c|}{ Severity of gastrointstinal disease } \\
\hline Mild & $14(29)$ \\
\hline Severe & $35(71)$ \\
\hline \multicolumn{2}{|l|}{ Severity of respiratory disease } \\
\hline Mild & $21(43)$ \\
\hline Severe & $28(57)$ \\
\hline
\end{tabular}

${ }^{\mathrm{a}}$ Data are presented as No. (\%).

value $=0.001)$. Mean serum ADA in CF patients with mild and severe gastrointestinal involvement was $8.87 \pm 2.38$ and $9.58 \pm 2.85$, respectively $(\mathrm{P}$ value $=0.41$ ). Mean serum ADA in CF patients with normal BMI was $10.3 \pm 2.7$ that was higher than in patients with low BMI $(7.9 \pm 2.08)(\mathrm{P}$ value $=$ 0.002 ). Mean serum ADA in CF patients with consanguinity of parents was lower than in those without consanguinity $($ P value $=0.01)($ Table 2$)$.

\section{Discussion}

Several studies have demonstrated a correlation between elevations in lung adenosine levels and development of pulmonary fibrosis $(1,5,16)$.

The mechanisms by which adenosine elevation leads to pulmonary fibrosis are not clear; however, it might activate the profibrotic pathways in the lung. ADA-deficient mice accumulate adenosine in multiple tissues, including the lung, where adenosine contributes to the development of pulmonary inflammation (1). It has been reported that TGF- $\beta 1$ is elevated in the lungs of partially ADAdeficient mice, suggesting that this molecule may increase the abundance of myofibroblasts and collagen deposition (1).

Although the direct stimulation of TGF- $\beta 1$ by adenosine has not been shown, the use of exogenous ADA en- 
Table 2. The Level of Serum ADA in CF Patients and Control Group

\begin{tabular}{|c|c|c|}
\hline Variables & Mean \pm SD & P Value \\
\hline Severity of respiratory disease & & 0.001 \\
\hline \multicolumn{3}{|l|}{ CF patients } \\
\hline Severe & $10.8 \pm 2.45$ & \\
\hline Mild & $7.14 \pm 1.19$ & \\
\hline Control & $16.04 \pm 3.9$ & \\
\hline Severity of gastrointstinal disease & & 0.41 \\
\hline \multicolumn{3}{|l|}{ CF patients } \\
\hline Severe & $9.58 \pm 2.85$ & \\
\hline Mild & $8.87 \pm 2.38$ & \\
\hline Control & $16.04 \pm 1.2$ & \\
\hline \multicolumn{3}{|l|}{ BMI, $\mathrm{Kg} / \mathrm{m}^{2}$} \\
\hline CF patients & & 0.002 \\
\hline Low (abnormal) & $7.9 \pm 2.08$ & \\
\hline Normal & $10.3 \pm 2.7$ & \\
\hline Control & & 0.4 \\
\hline Low (abnormal) & $16.2 \pm 1.3$ & \\
\hline Normal & $15.9 \pm 1.2$ & \\
\hline \multicolumn{3}{|l|}{ Consanguinity of parents } \\
\hline CF patients & & 0.01 \\
\hline Near consanguinity & $8.6 \pm 2.09$ & \\
\hline Distant consanguinity & $10.8 \pm 4.2$ & \\
\hline No consanguinity & $11.5 \pm 2.3$ & \\
\hline Control & & 0.6 \\
\hline Near consanguinity & $15.7 \pm 1.1$ & \\
\hline Distant consanguinity & $16.1 \pm 1.5$ & \\
\hline No consanguinity & $16.1 \pm 1.2$ & \\
\hline
\end{tabular}

zyme therapy in completely ADA-deficient mice led to lower adenosine levels in the lung and resolved the pulmonary fibrosis (16).

In this study, the mean serum ADA decreased in CF patients compared to control group. There are rare data on the level of serum ADA in CF patients. In the study of Perris et al. in Argentina, the increase in the activity of ADA was observed in patients with CF (17).

Interestingly, in our study the ADA level was lower in CF children with parental consanguinity compared to children without parental consanguinity $(P$ value $=0.01$ ), while the difference was not significant in control children with and without parental consanguinity. In addition, the lower level of ADA was found in CF patients with low BMI compared to CF patients with normal BMI (P value $=0.002)$.
In Goodarzi et al. study, the serum level of ADA was decreased in COPD patients (11).Vass et al. demonstrated a protective role of ADA and a pro-inflammatory function for adenosine in asthmatic patients (12). In addition, Hirsh et al. suggested that airway inflammation is due to increased level of adenosine in airway (18).

It has been reported that 8-cyclopentyl1,3-dipropylxanthine (CPX) and 1,3-diallyl-8cyclohexylxanthine (DAX), the adenosine antagonists, could improve the symptoms in CF patients through reduction of adenosine (19). According to previous reports $(20,21)$, the increased level of serum adenosine and disorder of alveogenesis was seen in ADA-deficient mice and its treatment with polyethylene glycol-modified ADA (PEG-ADA) - improved the alveolar growth and clinical 
symptoms.

Advances in understanding the role of adenosine in respiratory diseases should lead to effective treatment options. Pharmacological manipulation of adenosine signaling pathway is of great interest and exploitation of new therapeutic target with agonist and antagonist activities against known adenosine receptors would be so useful for the treatment of different conditions of the respiratory system and cystic fibrosis (22).

In addition, the uses of ADA enzyme therapy are able to prevent the abnormal alveolar development by prevention of adenosine and to a lesser extent deoxyadenosine accumulation in the lung (20).

In conclusion, the clinical symptoms in CF Patients especially respiratory symptoms might be associated with reduction of serum ADA and rising serum adenosine; therefore, further studies on the use of ADA enzyme therapy in CF patients and exploring new therapeutic targets with agonists and antagonists of adenosine receptors are highly recommended.

\section{References}

1. Chunn JL, Mohsenin A, Young HW, Lee CG, Elias JA, Kellems RE, et al. Partially adenosine deaminase-deficient mice develop pulmonary fibrosis in association with adenosine elevations. Am J Physiol Lung Cell Mol Physiol. 2006;290(3):L579-87. doi: 10.1152/ajplung.00258.2005. [PubMed: 16258000].

2. Cristalli G, Costanzi S, Lambertucci C, Lupidi G, Vittori S, Volpini $\mathrm{R}$, et al. Adenosine deaminase: functional implications and different classes of inhibitors. Med Res Rev. 2001;21(2):105-28. [PubMed: 11223861].

3. Walker BA, Jacobson MA, Knight DA, Salvatore CA, Weir T, Zhou D, et al. Adenosine A3 receptor expression and function in eosinophils. Am J Respir Cell Mol Biol. 1997;16(5):531-7. doi: 10.1165/ajrcmb.16.5.9160835. [PubMed: 9160835].

4. Young HW, Molina JG, Dimina D, Zhong H, Jacobson M, Chan LN, et al A3 adenosine receptor signaling contributes to airway inflammation and mucus production in adenosine deaminase-deficient mice. J Immunol. 2004;173(2):1380-9. [PubMed: 15240734].

5. Blackburn MR, Lee CG, Young HW, Zhu Z, Chunn JL, Kang MJ, et al. Adenosine mediates IL-13-induced inflammation and remodeling in the lung and interacts in an IL-13-adenosine amplification pathway. J Clin Invest. 2003;112(3):332-44. doi: 10.1172/JCI16815. [PubMed: 12897202].

6. Blackburn MR, Kellems RE. Adenosine deaminase deficiency: metabolic basis of immune deficiency and pulmonary inflammation. Adv Immunol. 2005;86:1-41. doi: 10.1016/S0065-2776(04)86001-2. [PubMed: 15705418].

7. Apasov SG, Blackburn MR, Kellems RE, Smith PT, Sitkovsky MV. Adenosine deaminase deficiency increases thymic apoptosis and causes defective T cell receptor signaling. J Clin Invest. 2001;108(1):131-41. doi: 10.1172/JCI10360. [PubMed: 11435465].
8. Afrasiabian S, Mohsenpour B, Haji Bagheri K, Sigari N, Aftabi K. Diagnostic value of serum adenosine deaminase level in pulmonary tuberculosis. J Res Med Sci. 2013;18(3):252.

9. Chander A, Shrestha CD. Diagnostic value of serum adenosine deam inase levels in sputum smear negative pulmonary tuberculosis patients in Nepalese population. Asian PacJTrop Biomed. 2012;2(3):S18969. doi: 10.1016/s2221-1691(12)60517-6.

10. Feliu MS, Perris P, Slobodianik N. Adenosine deaminase: as indicator of nutritional status. FASEB J. 2008;22(1 MeetingAbstracts):1102.2.

11. Goodarzi MT, Abdi M, Tavilani H, Nadi E, Rashidi M. Adenosine deaminase activity in COPD patients and healthy subjects. Iran J Allergy Asthma Immunol. 2010;9(1):7-12. [PubMed: 20548128].

12. Vass G, Horvath I. Adenosine and adenosine receptors in the pathomechanism and treatment of respiratory diseases. Curr Med Chem. 2008;15(9):917-22. [PubMed: 18473799].

13. Aldrich MB, Blackburn MR, Kellems RE. The importance of adenosine deaminase for lymphocyte development and function. Biochem Biophys Res Commun. 2000;272(2):311-5. doi: 10.1006/bbrc.2000.2773. [PubMed: 10833410].

14. Bagheri-Hanson A, Nedwed S, Rueckes-Nilges C, Naehrlich L. Intestinal current measurement versus nasal potential difference measurements for diagnosis of cystic fibrosis: a case-control study. BMC Pulm Med. 2014;14:156. doi: 10.1186/1471-2466-14-156. [PubMed: 25280757].

15. De Boeck K, Wilschanski M, Castellani C, Taylor C, Cuppens H, Dodge J, et al. Cystic fibrosis: terminology and diagnostic algorithms. Thorax. 2006;61(7):627-35. doi: 10.1136/thx.2005.043539. [PubMed: 16384879].

16. Chunn JL, Molina JG, Mi T, Xia Y, Kellems RE, Blackburn MR. Adenosinedependent pulmonary fibrosis in adenosine deaminase-deficient mice. J Immunol. 2005;175(3):1937-46. [PubMed: 16034138].

17. Perris P, Feliu MS, Barbeito S, Strasnoy I, Ferraro M, Slobodianik N. Serum C3c and C4c concentrations and adenosine deaminase activity of children with cystic fibrosis: preliminary study. Proc Nutr Soc. 2008;67(OCE1):E59. .

18. Hirsh AJ, Stonebraker JR, van Heusden CA, Lazarowski ER, Boucher $\mathrm{RC}$, Picher M. Adenosine deaminase 1 and concentrative nucleoside transporters 2 and 3 regulate adenosine on the apical surface of human airway epithelia: implications for inflammatory lung diseases. Biochemistry. 2007;46(36):10373-83. doi: 10.1021/bi7009647. [PubMed: 17696452].

19. Arispe N, Ma J, Jacobson KA, Pollard HB. Direct activation of cystic fibrosis transmembrane conductance regulator channels by 8-cyclopentyl-1,3-dipropylxanthine (CPX) and 1,3-diallyl-8cyclohexylxanthine(DAX).JBiol Chem. 1998;273(10):5727-34. [PubMed 9488705].

20. Banerjee SK, Young HW, Barczak A, Erle DJ, Blackburn MR. Abnormal alveolar development associated with elevated adenine nucleosides. Am J Respir Cell Mol Biol. 2004;30(1):38-50. doi: 10.1165/rcmb.20030102OC. [PubMed: 12855405].

21. Blackburn MR, Volmer JB, Thrasher JL, Zhong H, Crosby JR, Lee JJ, et al. Metabolic Consequences of Adenosine Deaminase Deficiency in Mice Are Associated with Defects in Alveogenesis, Pulmonary Inflammation, and Airway Obstruction.JExperMed. 2000;192(2):159-70. doi: 10.1084/jem.192.2.159.

22. Caruso M, Alamo A, Crisafulli E, Raciti C, Fisichella A, Polosa R. Adenosine signaling pathways as potential therapeutic targets in respiratory disease. Expert Opin Ther Targets. 2013;17(7):761-72. doi 10.1517/14728222.2013.795220. [PubMed: 23642090]. 